\title{
A controlled trial of acute effects of human exposure to traffic particles on pulmonary oxidative stress and heart rate variability
}

Robert J Laumbach ${ }^{1 *}$, Howard M Kipen ${ }^{1}$, Susan Ko ${ }^{1}$, Kathie Kelly-McNeil ${ }^{1}$, Clarimel Cepeda ${ }^{1}$, Ashley Pettit ${ }^{1}$, Pamela Ohman-Strickland ${ }^{3}$, Lin Zhang ${ }^{4}$, Junfeng Zhang ${ }^{4}$, Jicheng Gong ${ }^{4}$, Manoj Veleeparambil ${ }^{2}$ and Andrew J Gow ${ }^{5}$

\begin{abstract}
Background: For many individuals, daily commuting activities on roadways account for a substantial proportion of total exposure, as well as peak-level exposures, to traffic-related air pollutants (TRAPS) including ultrafine particles, but the health impacts of these exposures are not well-understood. We sought to determine if exposure to TRAPs particles during commuting causes acute oxidative stress in the respiratory tract or changes in heart rate variability (HRV), a measure of autonomic activity.

Methods: We conducted a randomized, cross-over trial in which twenty-one young adults took two 1.5-hr rides in a passenger vehicle in morning rush-hour traffic. The subjects wore a powered-air-purifying respirator, and were blinded to high-efficiency particulate air (HEPA) filtration during one of the rides. At time points before and after the rides, we measured HRV and markers of oxidative stress in exhaled breath condensate (EBC) including nitrite, the sum of nitrite and nitrate, malondialdehyde, and 8-isoprostane. We used mixed linear models to evaluate the effect of exposure on EBC and HRV outcomes, adjusting for pre-exposure response levels. We used linear models to examine the effects of particle concentrations on EBC outcomes at post-exposure time points.

Results: Mean EBC nitrite and the sum of nitrite and nitrate were increased from baseline at immediately post-exposure comparing unfiltered to filtered rides $(2.11 \mu \mathrm{M}$ vs $1.70 \mu \mathrm{M}, \mathrm{p}=0.02$ and $19.1 \mu \mathrm{M}$ vs $10.0 \mu \mathrm{M}$, $p=0.02$, respectively). Mean EBC malondialdehyde (MDA) concentrations were about $10 \%$ greater following the unfiltered vs. filtered exposures, although this result was not statistically significant. We found no significant associations between exposure to traffic particles and HRV outcomes at any of the time points. At immediately post-exposure, an interquartile range increase in particle number concentration was associated with statistically significant increases in nitrite $(99.4 \%, 95 \% \mathrm{Cl} 32.1 \%$ to $166.7 \%)$ and nitrite + nitrate $(75.7 \%, 95 \% \mathrm{Cl} 21.5 \%$ to $130.0 \%)$.
\end{abstract}

Conclusions: Increases in markers of oxidative stress in EBC may represent early biological responses to widespread exposures to TRAPs particles that affect passengers in vehicles on heavily trafficked roadways.

Keywords: Particles, Traffic, Vehicle emissions, Oxidative stress, Heart rate variability, Exhaled breath condensate, Nitrite, Nitrate

\footnotetext{
* Correspondence: laumbach@eohsi.rutgers.edu

${ }^{1}$ Department of Environmental and Occupational Medicine and the

Environmental and Occupational Health Sciences Institute, Rutgers Robert

Wood Johnson Medical School, 170 Frelinghuysen Rd, Piscataway, NJ 08854,

USA

Full list of author information is available at the end of the article
}

\section{Biomed Central}

(c) 2014 Laumbach et al.; licensee BioMed Central Ltd. This is an Open Access article distributed under the terms of the Creative Commons Attribution License (http://creativecommons.org/licenses/by/4.0), which permits unrestricted use, distribution, and reproduction in any medium, provided the original work is properly credited. The Creative Commons Public Domain Dedication waiver (http://creativecommons.org/publicdomain/zero/1.0/) applies to the data made available in this article, unless otherwise stated. 


\section{Background}

Exposure to traffic-related air pollutants (TRAPs) has been associated with cardiovascular and respiratory health effects [1-3]. Exposure to TRAPs is highly prevalent, and for many individuals, a substantial proportion of daily exposure to TRAPs occurs during work commutes in rush-hour traffic [4]. Although the health effects of these short-term, intense exposures to TRAPs are not wellestablished, a case-crossover study found increased risk of myocardial infarction within hours of commuting activities [5]. Controlled exposure to emissions from diesel engines, a major source of TRAPs, caused acute respiratory irritation, inflammation, and adverse cardiovascular effects among human volunteers [6-12]. Short-term exposures to TRAPs on or near roadways have been associated with increased respiratory tract inflammation, decreased lung function, and changes in heart rate variability (HRV) [13-19].

Oxidative stress is a general mechanism by which exposure to TRAPs may cause adverse health effects [2,20]. Complex TRAPs mixtures include known primary oxidants, notably PAH-quinones and transition metals found in the particle phase [21-23]. Cellular interactions with TRAPs cause secondary production of oxidants, including nitric oxide and nitrosative compounds, as well as reactive oxygen species [24,25]. Oxidative stress has been implicated in inflammatory responses to diesel exhaust and diesel exhaust particles in cell systems, animal models, and the human respiratory tract $[26,27]$.

Pulmonary oxidative stress can be sampled non-invasively with exhaled breath condensate (EBC). In EBC, concentrations of the nitrite and nitrate, relatively stable oxidation products of nitric oxide metabolism, have been associated with previous-day exposure to coarse particles among adults with pulmonary disease in European cities [28], and with levels of air pollution in healthy adults during the Beijing Olympics time period [29]. We found increased EBC nitrite and nitrate among adults with asthma after controlled exposure to diesel exhaust [9]. Increased concentrations of the lipid peroxidation products malondialdehyde (MDA) and 8-isoprostane have been associated with exposure to PM and traffic among children with asthma in Mexico City [30] and with ambient PM among students in Beijing $[31,32]$.

Exposures to ambient and traffic-related particulate matter (PM) have been associated with adverse cardiovascular effects, including changes in heart rate variability (HRV), an indicator of the relative balance of parasympathetic and sympathetic autonomic control of heart rate that has predicted mortality in at-risk patient groups [33]. Polymorphisms in antioxidant genes modify associations between ambient PM and HRV, suggesting a link between oxidative stress and the autonomic effects of exposure to PM $[34,35]$.
We hypothesized that 1.5 -hr rides as a passenger in an automobile in morning rush-hour traffic on a major US highway causes acute increases in oxidative stress in the respiratory tract and changes in autonomic balance among healthy young adults, and that the PM component of the TRAP mixture is responsible for these effects. We measured changes in biomarkers of oxidative stress in EBC and HRV in a randomized, controlled, cross-over study design in which subjects wore a powered air purifying respirator (PAPR) during two car rides, and were blinded to High Efficiency Particulate Air (HEPA) filtration during one of the two car rides. Both inside the respirator and inside the vehicle cabin, we measured $\mathrm{PM}_{2.5}$ (particulate matter with median aerodynamic diameter cut-point of $<2.5 \mu \mathrm{m}$ ) and particle number $(\mathrm{PN})$ concentration as a proxy for ultrafine particles on roadways in traffic.

\section{Results}

\section{Demographics}

The subjects (mean age 22 years old) were predominantly male, reflecting the population of our academic campus at Rutgers University (Table 1).

\section{Exposure measurements}

With the HEPA filter in place, the mean (+/-SD) particle number concentration that subjects breathed inside the respirator hood was reduced by approximately 99.99\% compared to unfiltered rides $(3.5+/-4.1$ vs. $37,999+/-9,545 \mathrm{pt} / \mathrm{cm}^{3}$ ) (Table 2) (Figure 1). The reduction in $\mathrm{PM}_{2.5}$ with HEPA filtration was of a much smaller magnitude $\left(9.1+/-4.8\right.$ vs. $\left.1.4+/-0.6 \mu \mathrm{g} / \mathrm{m}^{3}\right)$. Black carbon and gas-phase pollutants were not measured inside the respirator. Mean concentrations of black carbon, $\mathrm{CO}, \mathrm{NO}_{2}, \mathrm{~T}$ and $\mathrm{RH}$ in the vehicle cabin air were similar on filtered vs. unfiltered days.

Subjects wore the PAPR during both car rides, blinded to the presence or absence of the HEPA filter. The filter

\section{Table 1 Characteristics of subjects}

\begin{tabular}{ll}
\hline Characteristic & Mean (range) \\
\hline Age (years) & $22.4(18-41)$ \\
BMI $\left(\mathrm{kg} / \mathrm{m}^{2}\right)$ & $23.8(19.50-28.66)$ \\
Race/ethnicity & $\mathbf{n}(\%)$ \\
Asian & $9(43)$ \\
Black & $3(14)$ \\
Hispanic & $1(5)$ \\
White & $8(38)$ \\
Sex & $\mathbf{n}(\%)$ \\
Men & $15(71)$ \\
Women & $6(29)$ \\
\hline
\end{tabular}


Table 2 Concentrations (mean \pm SD) of measured pollutants

\begin{tabular}{|c|c|c|c|c|c|c|}
\hline \multirow[t]{2}{*}{ Environmental measurements } & \multicolumn{3}{|c|}{ Unfiltered rides } & \multicolumn{3}{|c|}{ HEPA-filtered rides } \\
\hline & Mean & SD & Median & Mean & SD & Median \\
\hline \multicolumn{7}{|l|}{ Air inside vehicle cabin } \\
\hline Particle Number $\left(\mathrm{cm}^{-3}\right)$ & 41,350 & 12,678 & 40,806 & 44,411 & 16,115 & 40,063 \\
\hline $\mathrm{PM}_{2.5}\left(\mu \mathrm{g} / \mathrm{m}^{3}\right)$ & 11.7 & 6.3 & 10.7 & 12.2 & 6.2 & 10.3 \\
\hline$B C\left(\mu \mathrm{g} / \mathrm{m}^{3}\right)$ & 6.1 & 3.6 & 5.5 & 6.2 & 2.5 & 6.2 \\
\hline $\mathrm{CO}(\mathrm{ppm})$ & 1.1 & 0.4 & 1.1 & 1.3 & 0.4 & 1.2 \\
\hline $\mathrm{NO} 2$ (ppb) & 26 & 9 & 26 & 26 & 11 & 24 \\
\hline Temp ${ }^{\circ} \mathrm{C}$ & 24.5 & 2.9 & 24.2 & 23.6 & 2.4 & 23.8 \\
\hline $\mathrm{RH} \%$ & 25 & 10 & 28 & 27 & 10 & 28 \\
\hline \multicolumn{7}{|l|}{ Air inside respirator facepiece } \\
\hline Particle number $\left(\mathrm{cm}^{-3}\right)$ & 37,999 & 9,545 & 37,928 & 3.5 & 4.1 & 2.2 \\
\hline PM2.5 $\left(\mu \mathrm{g} / \mathrm{m}^{3}\right)$ & 9.1 & 4.8 & 8.2 & 1.4 & 0.6 & 1.3 \\
\hline
\end{tabular}

Abbreviations: HEPA High-Efficiency Particulate Air.

Pollutant measurements were made in the vehicle cabin air and inside the facepiece of the respirator (particle number and PM2.5 only) during all rides under both unfiltered and filtered conditions.

is not visible inside the PAPR, and the respirator is very quiet and maintains constant airflow and a positive pressure inside the loose-fitting face piece with or without the filter in place. Stress Questionnaire data showed no difference in perceived stress or anxiety during the car rides while wearing the PAPR compared to prior to the car rides while not wearing the PAPR [Stress Symptom Rating (SSR) mean score (SD): 2.05 (0.81) vs. 2.06 (0.95)].

\section{EBC markers}

Figure 2 shows concentrations of nitrite, the sum of nitrite and nitrate (nitrite + nitrate), and MDA in EBC collected at pre-exposure, post-exposure, $6 \mathrm{hr}$, and $24 \mathrm{hr}$ after the car rides. Following the unfiltered rides, mean EBC nitrite was increased at post-exposure compared to baseline $(2.11 \mu \mathrm{M}$ vs $1.70 \mu \mathrm{M})$, whereas following the filtered rides, mean EBC nitrite decreased at post-exposure compared to baseline $(1.14 \mu \mathrm{M}$ vs. $1.56 \mu \mathrm{M}) \quad(\mathrm{p}=0.02$ comparing change from baseline in filtered vs. unfiltered).

In the unfiltered rides, mean EBC nitrite + nitrate was increased at post-exposure compared to baseline $(19.1 \mu \mathrm{M}$ vs $10.0 \mu \mathrm{M}$ ), whereas in the filtered rides, mean EBC nitrite + nitrate decreased at post-exposure compared to baseline $(13.1 \mu \mathrm{M}$ vs $16.9 \mu \mathrm{M})(\mathrm{p}=0.02$ comparing change from baseline in filtered vs. unfiltered). Changes in mean $\mathrm{EBC}$ nitrite + nitrate from baseline, comparing filtered and unfiltered rides, were not statistically significantly different at $6 \mathrm{hr}$ and $24 \mathrm{hr}$ after the rides.

Mean MDA concentrations in EBC were about 10\% greater in the unfiltered vs. filtered conditions at postexposure, $6 \mathrm{hr}$, and $24 \mathrm{hr}$, but these differences were not statistically significant. EBC 8-isoprostane was not detectable in a majority of the samples using our HPLC method.
In regression analysis of data from filtered and unfiltered rides, an interquartile range (IQR) increase in particle number concentration $\left(36,392 / \mathrm{cm}^{3}\right)$, measured inside the respirator face piece, was associated with statistically significant increases in nitrite and nitrite + nitrate at the immediately post exposure time point, but not at the 6 and $24 \mathrm{hr}$ time points (Table 3 ). There were no statistically significant associations between $\mathrm{PM}_{2.5}$ (IQR $5.25 \mu \mathrm{g} / \mathrm{m}^{3}$ measured inside the respirator and $\mathrm{EBC}$ nitrite, nitrite + nitrate, or MDA.

\section{Heart rate and HRV}

HRV parameters generally decreased from pre-exposure to $6 \mathrm{hr}$ and $24 \mathrm{hr}$ for both filtered and unfiltered rides, but there were no statistically significant differences between unfiltered and filtered rides (Table 4). Similarly, LF and total power increased from baseline to post-exposure, but with no statistically significant differences between unfiltered and filtered rides. There were no consistent trends or statistically significant effects of exposure (filtered vs. unfiltered) on HRV or HR at any time points. There was a large amount of variation in HRV outcome measurements both within and between subjects.

\section{Discussion}

Among young adults riding as passengers for $90-110 \mathrm{~min}$ in heavy motor-vehicle traffic, we found increased nitrite and nitrite + nitrate in EBC immediately after rides during which the subjects breathed unfiltered vehicle cabin air compared to rides during which they breathed HEPAfiltered air. In analysis of single pollutant effects, mean particle number concentration measured inside the respirator was associated with increased nitrite and nitrite + nitrate in EBC immediately after the car rides. MDA 


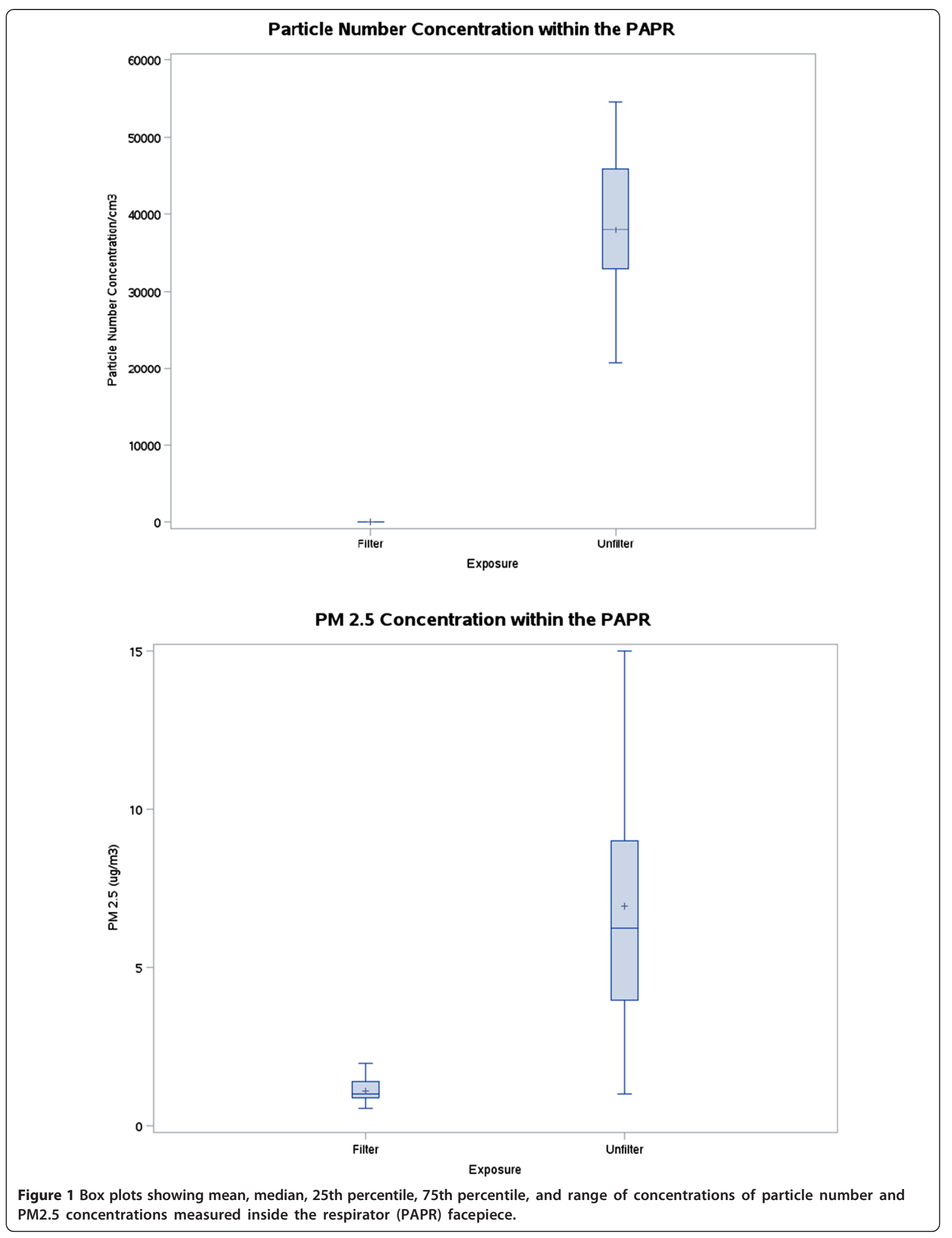



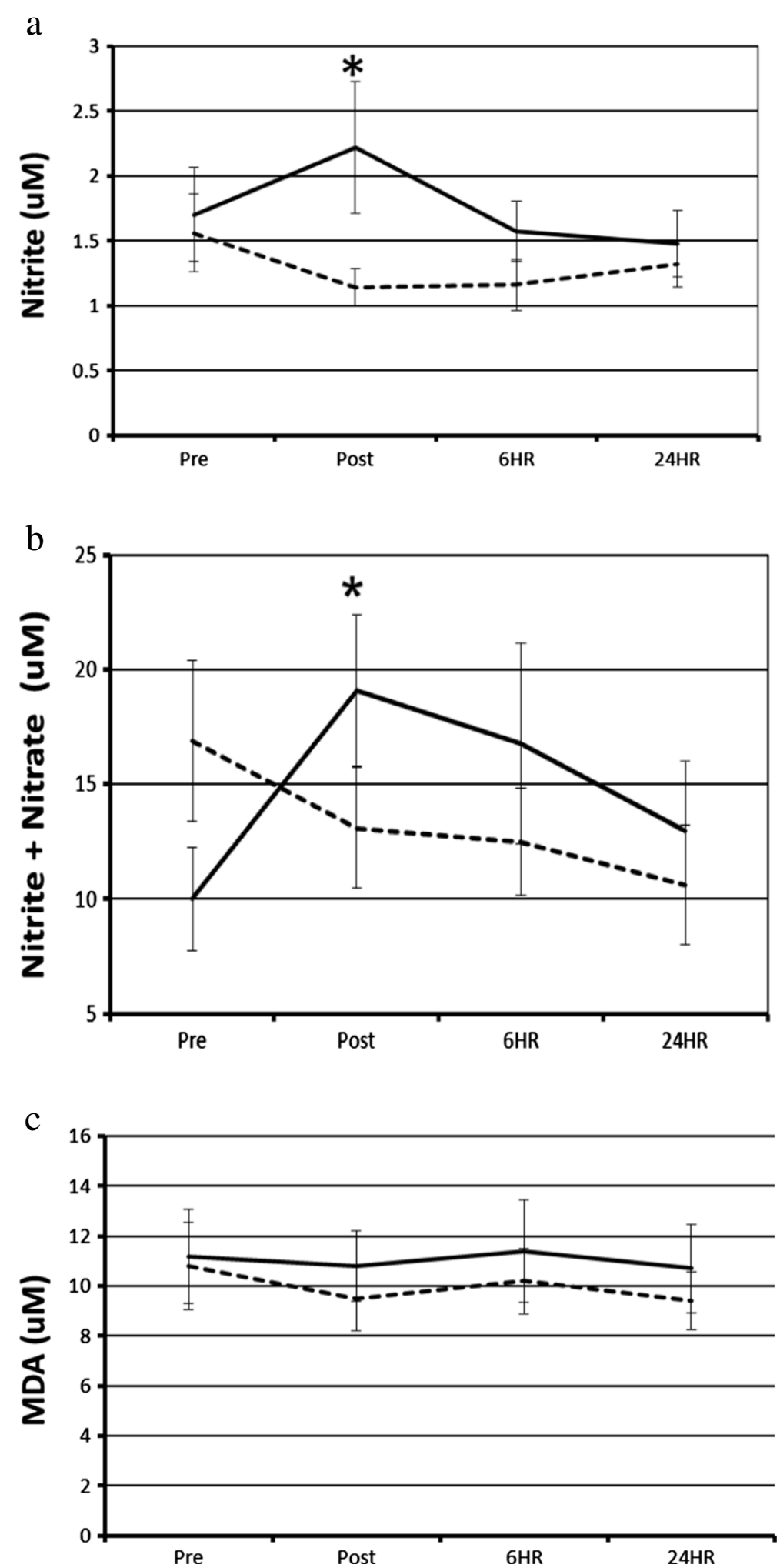

Figure 2 EBC outcome measurements before and after breathing either HEPA-filtered or unfiltered air during car rides. EBC nitrite (a), nitrite + nitrate (b), and MDA (c) at pre-exposure, immediately post-exposure, and 6 and $24 \mathrm{hr}$ post-exposure with HEPA filtered breathing air (dashed line) or unfiltered breathing air (solid line). $\mathrm{N}=20$ for most data points, with missing single data points at some 6 and 24 hours ( $N=19) *$ *indicates significance at $p=0.02$ for exposure effects comparing change from baseline for unfiltered rides to change from baseline for filtered rides. 
Table 3 Estimated\% difference $(95 \% \mathrm{Cl})$ in EBC nitrite, nitrite + nitrate, and malondialdehyde (MDA) associated with interquartile range change relative to the median, adjusted for pre-exposure level, in particle number concentration $\left(\mathrm{cm}^{-1}, \mathrm{PN}\right)$ and $\mathrm{PM} 2.5$ inside the respirator for all car rides

\begin{tabular}{|c|c|c|c|c|}
\hline \multirow{2}{*}{$\begin{array}{l}\text { EBC biomarker } \\
\text { Nitrite }\end{array}$} & \multirow{2}{*}{$\begin{array}{l}\text { Pollutant** } \\
\text { PN }\end{array}$} & \multirow{2}{*}{$\begin{array}{l}\text { Time pt. } \\
0 \mathrm{hr}\end{array}$} & \multicolumn{2}{|c|}{ \% Response/IQR increase } \\
\hline & & & $99.4 \%$ & $(32.1 \% \text { to } 166.7 \%)^{*}$ \\
\hline & & $6 \mathrm{hr}$ & $22.3 \%$ & $(-21.9 \%$ to $66.5 \%)$ \\
\hline & & $24 \mathrm{hr}$ & $7.1 \%$ & (-16.2\% to $29.8 \%)$ \\
\hline & PM2.5 & $0 \mathrm{hr}$ & $27.6 \%$ & $(-27.3 \%$ to $82.4 \%)$ \\
\hline & & $6 \mathrm{hr}$ & $13.2 \%$ & $(-18.6 \%$ to $45.0 \%)$ \\
\hline & & $24 \mathrm{hr}$ & $-1.9 \%$ & $(-10.0 \%$ to $6.2 \%)$ \\
\hline \multirow[t]{6}{*}{ Nitrite + Nitrate } & PN & $0 \mathrm{hr}$ & $75.7 \%$ & $(21.5 \% \text { to } 130.0 \%)^{*}$ \\
\hline & & $6 \mathrm{hr}$ & $62.9 \%$ & $(-35.5 \%$ to $160.3 \%)$ \\
\hline & & $24 \mathrm{hr}$ & $33.5 \%$ & $(-18.6 \%$ to $85.2 \%)$ \\
\hline & PM2.5 & $0 \mathrm{hr}$ & $26.4 \%$ & $(-13.7 \%$ to $66.5 \%)$ \\
\hline & & $6 \mathrm{hr}$ & $8.9 \%$ & (-61.0\% to $78.8 \%)$ \\
\hline & & $24 \mathrm{hr}$ & $7.8 \%$ & $(-33.0 \%$ to $48.6 \%)$ \\
\hline \multirow[t]{6}{*}{ MDA } & PN & $0 \mathrm{hr}$ & $11.3 \%$ & $(-16.2 \%$ to $37.3 \%)$ \\
\hline & & $6 \mathrm{hr}$ & $0.3 \%$ & (-43.2\% to $42.7 \%)$ \\
\hline & & $24 \mathrm{hr}$ & $15.1 \%$ & (-16.8\% to $47.1 \%)$ \\
\hline & PM2.5 & $0 \mathrm{hr}$ & $-1.4 \%$ & ( $-20.6 \%$ to $17.9 \%)$ \\
\hline & & $6 \mathrm{hr}$ & $3.8 \%$ & $(-27.0 \%$ to $34.5 \%)$ \\
\hline & & $24 \mathrm{hr}$ & $1.1 \%$ & (-24.3\% to $26.6 \%)$ \\
\hline
\end{tabular}

${ }^{*} p<0.01$ for change from baseline.

**Inter-quartile ranges: $\mathrm{PN}=36,392, \mathrm{PM} 2.5=5.25, \mathrm{BC}=4.66$.

concentrations in $\mathrm{EBC}$ were $\sim 12$ to $14 \%$ greater at postexposure and 6 and $24 \mathrm{hr}$ after unfiltered compared to filtered rides, but these differences were not statisticallysignificant. We did not find statistically significant differences in HRV between unfiltered and filtered rides. These results suggest that exposure to the particle phase of TRAP contributes to acute, transient increases in respiratory tract oxidative stress among healthy adult vehicle occupants during short-term exposures to TRAP that occur during commuting.

We used an experimental approach with a filtered-air control condition in order to isolate the effects of exposure to TRAP particles on biomarkers of acute oxidative stress and autonomic balance that may mediate respiratory and cardiovascular health effects of relatively intense, short-term exposures to TRAPs. TRAPs are a complex mixture of primary gas-, vapor-, and particle-phase pollutants from engine emissions, as well as re-suspended road dust and products of vehicle and road wear. In various settings in close proximity to sources, such as while occupying a vehicle in traffic or residing near a major roadway, exposures to TRAP are likely to co-vary with noise, other environmental factors, and psychological stress. Observational epidemiologic approaches may have limited ability to disentangle the effects of specific components of TRAPs from the effects of these potentially confounding or effectmodifying co-exposures. Controlled human exposure studies in the laboratory can control for potential confounders, but generally with some sacrifice of relevance to complex real-world exposures. To control for these factors in a realworld setting, we randomized exposure to HEPA-filtered and unfiltered vehicle cabin air in a blinded, cross-over study design. The observed differences between unfiltered (particles and gas-phase TRAPs) and particle-filtered (gasphase TRAPs only) exposures suggest that particles are necessary, although they may not be sufficient, to cause the observed increases in markers of oxidative stress in the respiratory tract after exposure to TRAPs.

This is the first report of acute increases in markers of oxidative stress in EBC following short-term, real-world exposure to TRAPs. In a recent controlled exposure study, we found increases in EBC nitrite in subjects with asthma immediately after a 1-hr exposure to diluted diesel exhaust compared to filtered-air control [9]. Balint et al. (2001) reported an immediate, transient increase in EBC nitrite + nitrate among smokers after smoking two cigarettes [36]. Other studies have found that EBC nitrite and/or nitrite + nitrate were positively associated with levels of ambient air pollution [28,29], as well as with the disease states of asthma, cystic fibrosis, and COPD [37-39].

We found statistically significant associations between particle number concentrations and EBC nitrite and nitrite + nitrate immediately following the car rides, but no associations between $\mathrm{PM}_{2.5}$ and these outcomes. Particle number is a more specific indicator of TRAP particles, which are predominantly in the ultrafine size range near emission sources on highways, compared to $\mathrm{PM}_{2.5}$ mass concentration, which includes generally larger ambient particles and is less influenced by TRAP particles [40]. Therefore, these results are consistent with the interpretation that exposure to TRAP particles, not ambient PM, were a primary cause of the airway response measured in $\mathrm{EBC}$ comparing unfiltered to filtered rides.

Increases in nitrite and nitrate in $\mathrm{EBC}$ may reflect increased NO production and/or increased oxidation of NO to nitrite and/or nitrite to nitrate. Although both EBC nitrite and fractional exhaled nitric oxide (FENO) can indicate the level of NO production within the lung, there are significant differences between the two measures. By definition, FENO is a measure of NO released to the gas phase that has escaped reaction with aqueous components of the lung lining. In contrast, nitrite represents NO that has been "fixed" in the aqueous phase by oxidative reactivity. Therefore, EBC nitrite is a more complex measure as it is determined by the rates of NO production and oxidation. The immediate increase in $\mathrm{EBC}$ nitrite was consistent with increased NO production from the constitutive isoforms of nitric oxide synthase (NOS), rather than 
Table 4 Heart rate variability (HRV) at time points before and after unfiltered and filtered care rides

\begin{tabular}{|c|c|c|c|c|c|c|c|c|}
\hline \multirow[t]{2}{*}{ Out-come } & \multirow[t]{2}{*}{ Exposure } & \multicolumn{4}{|l|}{ Mean (SD) } & \multicolumn{3}{|c|}{ Mean of differences from pre-exposure (SD) } \\
\hline & & Pre-exposure $^{a}$ & Immediately Post ${ }^{\text {b }}$ & 6 hours post $^{a}$ & 24 hours post $^{c}$ & Immediately Post & 6 hours post & 24 hours post \\
\hline \multirow[t]{3}{*}{ RMSSD (ms) } & Filtered & $0.095(0.066)$ & $0.103(0.064)$ & $0.064(0.042)$ & $0.082(0.056)$ & $0.008(0.028)$ & $-0.031(0.043)$ & $-0.011(0.043)$ \\
\hline & Unfiltered & $0.073(0.048)$ & $0.091(0.051)$ & $0.056(0.033)$ & $0.077(0.059)$ & $0.017(0.050)$ & $-0.016(0.046)$ & $0.077(0.070)$ \\
\hline & \multicolumn{5}{|c|}{$P$-value assessing exposure effect ${ }^{d}$} & .5180 & .91056 & .9756 \\
\hline \multirow[t]{3}{*}{$\operatorname{LF}\left(m s^{2}\right)$} & Filtered & $1152.6(1549.4)$ & $1575.8(1447.1)$ & $623.1(511.1)$ & $933.5(1045.4)$ & $423.2(1339.5)$ & $-529.6(1263.5)$ & $-237.6(1573.3)$ \\
\hline & Unfiltered & $1112.2(1005.2)$ & $1432.9(996.7)$ & $752.9(681.2)$ & $827.9(795.5)$ & $281.3(921.9)$ & $-359.3(733.0)$ & $-284.0(663.5)$ \\
\hline & \multicolumn{5}{|c|}{$P$-value assessing exposure effect ${ }^{d}$} & .3750 & .2530 & .7847 \\
\hline \multirow[t]{3}{*}{$\mathrm{HF}\left(m s^{2}\right)$} & Filtered & $2294.3(3646.1)$ & $2453.7(2993.9)$ & $1029.9(1116.5)$ & $1675.6(2562.2)$ & $159.4(1232.4)$ & $-1264.4(3220.3)$ & $-540.3(2110.6)$ \\
\hline & Unfiltered & $1908.1(2922.2)$ & $1882.6(1996.0)$ & $787.4(768.2)$ & $1613.0(3191.2)$ & $-94.3(1853.6)$ & $-1120.7(2560.8)$ & $-222.9(1456.3)$ \\
\hline & \multicolumn{5}{|c|}{$P$-value assessing exposure effect ${ }^{d}$} & .2893 & .2761 & .6482 \\
\hline \multirow[t]{3}{*}{$L F / H F\left(m s^{2}\right)$} & Filtered & $1.2(1.6)$ & $1.1(0.9)$ & $1.4(1.2)$ & $1.0(0.6)$ & $-0.1(1.1)$ & $0.3(1.7)$ & $-0.2(1.6)$ \\
\hline & UnFiltered & $1.2(0.9)$ & $1.3(1.1)$ & $1.3(0.8)$ & $1.1(1.1)$ & $0.1(0.9)$ & $0.1(0.7)$ & $-0.3(0.7)$ \\
\hline & \multicolumn{5}{|c|}{$P$-value assessing exposure effect ${ }^{d}$} & .3263 & .5061 & .8774 \\
\hline \multirow[t]{3}{*}{ Total Power $\left(\mathrm{ms}^{2}\right)$} & Filtered & $4644.2(4699.9)$ & $7879.1(8187.1)$ & $2699.3(1975.1)$ & $3891.0(3658.0)$ & $3234.9(7109.1)$ & $-1944.9(4061.6)$ & $-699.5(3503.1)$ \\
\hline & Unfiltered & $4391.9(4976.9)$ & $6338.7(5207.0)$ & $2948.1(2513.4)$ & $3652.7(4980.4)$ & $1828.7(3700.2)$ & $-1443.8(3190.1)$ & $-670.1(3559.9)$ \\
\hline & \multicolumn{5}{|c|}{$P$-value assessing exposure effect ${ }^{d}$} & .2795 & .4105 & .9899 \\
\hline \multirow[t]{3}{*}{$\mathrm{HR}\left(\mathrm{min}^{-1}\right)$} & Filtered & $60.1(9.5)$ & $56.8(7.9)$ & $68.9(12.8)$ & $61.3(8.2)$ & $-3.3(5.0)$ & $8.8(8.5)$ & $0.3(6.8)$ \\
\hline & Unfiltered & $61.4(10.2)$ & $59.4(9.7)$ & $70.2(11.8)$ & $63.3(11.8)$ & $-2.7(7.9)$ & $8.9(9.3)$ & $1.6(6.8)$ \\
\hline & \multicolumn{5}{|c|}{$P$-value assessing exposure effect ${ }^{d}$} & .4087 & .6640 & .5514 \\
\hline
\end{tabular}

${ }^{a} \mathrm{~N}=20$ for filtered; $\mathrm{N}=21$ for unfiltered; ${ }^{\mathrm{b}} \mathrm{N}=20$ for filtered and unfiltered; ${ }^{\mathrm{N}} \mathrm{N}=19$ for filtered $\mathrm{N}=21$ for unfiltered; ${ }^{\mathrm{d}}$ Derived from mixed-effects linear model, controlling for baseline as a covariate and nested sessions within subject.

Means and Standard Deviations of HRV outcomes at each time point, the changes from pre-exposure and p-values assessing the effect of exposure (unfiltered vs. HEPA-filtered ride) on change in HRV outcomes from pre-exposure baseline to post-exposure time points. 
inducible NOS2 activity, which requires protein synthesis. Consistent with increased production of $\mathrm{NO}$ in response to TRAP exposure, Adar et al. found that exposures to $\mathrm{PM}_{2.5}$ and black carbon were positively associated with FENO among elderly passengers on group diesel bus rides in St. Louis [41]. Even if the mechanism of response to inhaled TRAP particles were solely increased NO production, this represents a source of oxidative stress through NO's role as an oxidant.

The observed increase in MDA, a marker of lipid peroxidation, after unfiltered rides compared to filtered rides (Figure 1c) was consistent across time points, but not statistically significant. Longer-term exposures to air pollutants have been associated with MDA in EBC [30,31]. Among a panel of healthy adults, higher levels of EBC MDA were measured during the pre- and post-Olympic periods, compared to the Olympic period in Beijing, China when air pollutants were drastically reduced [31].

Comparing filtered to unfiltered rides, we found no statistically significant changes from baseline in any measured HRV parameters at post-exposure, 6 , or $24 \mathrm{hr}$ (Table 3). A recent meta-analysis of studies that included exposure to ambient or occupational PM demonstrated a significant inverse relationships between $\mathrm{PM}_{2.5}$ and $\mathrm{LF}, \mathrm{HF}, \mathrm{RMSSD}$ and SDNN HRV measurements [33]. Fewer studies have examined the effects of direct exposure to TRAPs on HRV, with inconsistent results $[14,19,42,43]$. The acute effects of diesel exhaust on HRV have been inconsistent in controlled exposure studies [44,45].

In a similar study design, Langrish et al. (2009) found that 24-hr SDNN and LF HRV were higher after 2-hr walks in central Beijing during which healthy subjects wore a negative pressure, air purifying ("N95") respirator, compared to walks without the respirator [12]. Negative pressure, air-purifying respirators are known to affect cardiovascular physiology including HR and BP, and subjects could not be blinded to the exposure conditions $[46,47]$. In the present study, we used a powered air purifying respirator that does not alter pulmonary mechanics, and subjects were blinded to the presence or absence of a HEPA filter in the light-weight, hood-type, respirator, which was worn for both filtered and unfiltered rides.

\section{Limitations}

The study was small and may have been underpowered to detect some effects that may be of biological significance, particularly changes in HRV and EBC MDA, especially in light of the relatively low exposure levels. The young healthy, university student subjects do not represent the general population and may not reflect the response of more susceptible populations. The comparisons between rides were between exposures to combined particle- and gas-phases (unfiltered rides) versus gas-phase TRAPs only (filtered rides). Therefore, we cannot attribute the observed effects on nitrite and nitrite + nitrate in EBC to the particles alone. It is possible that an interaction between particles and gas-phase compounds is essential to produce these effects.

We could not control the levels of exposure to PM during unfiltered rides and the variability in mean particle number concentration and $\mathrm{PM}_{2.5}$ measured inside the vehicle cabin were large (IQR 18,080 particle $/ \mathrm{cm}^{3}$ and $6.2 \mu \mathrm{g} / \mathrm{m}^{3}$, respectively). The relatively low levels of PM in the vehicle reflected real-world exposure conditions, but limited our power to see effects. Traffic pollutant mixtures in vehicles vary in concentration and in composition with different ambient and near-roadway conditions, vehicle types, and operating conditions [4].

The $\sim 99.99 \%$ reduction in particle number concentration with HEPA filtration (Table 2) is consistent with the expected, highly-efficient removal of ultrafine traffic particles. We speculate that the smaller reduction in $\mathrm{PM}_{2.5}$ of about $85 \%$ was due to re-suspension of previouslydeposited larger particles from the subjects' hair and skin surfaces as filtered air was delivered above the subject's head before flowing down to the subject's immediate breathing zone where we positioned the sampling ports. We believe these particles entered the breathing zone air downstream of the HEPA filter, which is rated at $\geq 99.97 \%$ removal of $0.3 \mu \mathrm{m}$ particles and is expected to be even more efficient at removing the larger particles that contribute to $\mathrm{PM}_{2.5}$ than the smaller particles that dominate the particle number concentration on roadways. However, we have not characterized these particles.

Several investigators have questioned the usefulness of EBC nitrite as a biomarker reflective of the lower respiratory tract $[48,49]$. A study of subjects with and without tracheostomy suggested that chemical reduction of salivary nitrate to nitrite by oropharyngeal bacteria made a substantial contribution to nitrite concentrations in EBC that was collected by oral breathing [48]. Dietary nitrate was found to strongly influence salivary nitrate and EBC nitrite concentrations. In our study, subjects fasted prior to the baseline and post-exposure EBC collections, and then were asked to eat similar foods during the postfast meals after filtered and unfiltered rides. Control of food consumption, along with the within-subjects, repeated-measures design, may have mitigated any effect of oropharyngeal contamination, which would likely be nondifferential, tending to bias results towards the null hypothesis.

\section{Conclusions}

In this study, nitrite and nitrite + nitrate in EBC were increased immediately after $1.5 \mathrm{hr}$ car rides when subjects breathed unfiltered vehicle cabin air, but not after rides when subjects breathed HEPA-filtered air, suggesting 
that TRAP particles play an essential role in these effects. There were no statistically significant differences in HRV or HR after unfiltered compared to filtered rides. The health significance of the observed effects is not known, but they may be indicative of early biological responses to widespread exposures to TRAPs among passengers in vehicles on heavily trafficked roadways.

\section{Methods}

We recruited 21 nonsmoking, healthy adults without serious chronic illness, pulmonary or cardiovascular disease, atrial flutter, atrial fibrillation, or cardiac pacing. All subjects lived on campus or within 10 miles of the clinical center Clinical Center of the Environmental and Occupational Health Sciences Institute (EOHSI) in Piscataway, NJ, except for one subject who lived 15 miles away. Eight subjects rode campus diesel buses from residences on the university campus; the remainder drove personal vehicles. The study protocol was approved by the University of Medicine and Dentistry of New Jersey Institutional Review Board.

\section{Study procedure}

Each subject participated in two nominally $1.5 \mathrm{hr}$ (range 90-110 min, depending on traffic) car rides in morning Monday-Friday rush-hour traffic, at least one week and no more than six weeks apart, in a 2002 Ford Taurus sedan. Subjects wore a powered air-purifying respirator (PAPR, Airmate ${ }^{\mathrm{Tx}}, 3 \mathrm{M}$, Minneapolis, MN) with a HEPA filter present during one ride (filtered ride), and absent during the other ride (unfiltered ride), in randomized order (Figure 3). Subjects and technicians were blinded

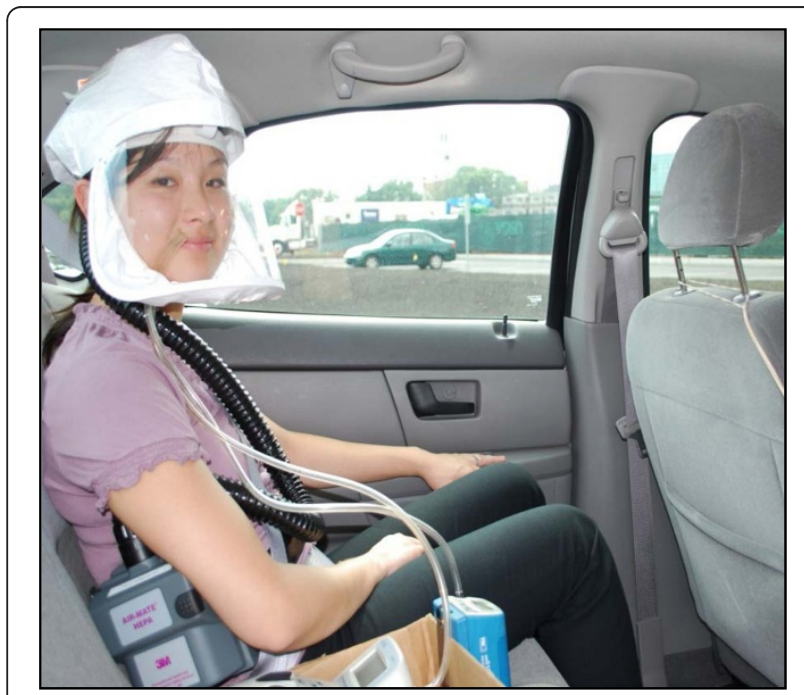

Figure 3 An investigator demonstrates set-up of the powered air purifying respirator, with sampling instrument inlets in place inside the respirator facepiece, as worn by subjects. to the presence or absence of the filter. Outcomes were measured before (pre-exposure), after (post-exposure), and at 6 and 24 hrs after the car rides began. To avoid effects of food ingestion on study outcomes, subjects fasted after midnight. Subjects were instructed to avoid major roadways if driving to the Clinical Center. Subjects reported at 7:00 AM for the pre-exposure session, which included a current stress symptom rating (SSR), consisting of five-point modified-Likert scales between two pairs of antonyms for "stress" (tense-relaxed; stressed-at ease) and "anxiety" (nervous-calm; jittery-tranquil). After electrocardiogram (ECG) recordings and EBC collection, subjects underwent non-invasive studies of endothelial function, and a peripheral venous blood draw, results of which will be reported elsewhere.

The subject was seated in the rear seat of the vehicle, which was driven by a professional driver from the EOHSI Clinical Center to and from the northernmost point on the New Jersey Turnpike (NJTPK; 79 miles roundtrip, of which 55 miles were on the NJTPK, 18 miles on Interstate 287, and 6 miles on local secondary roads). The NJTPK is a highway with six traffic lanes in each direction. The study vehicle remained in the right-most lane, designated for both trucks and cars, averaging $65 \mathrm{mph}$ when unimpeded by traffic. Stop-and-go traffic conditions were rarely encountered, and $50 \%$ of the rides lasted between 95 and 100 minutes. The vehicle ventilation settings were maintained with the vent "open" and fan at the medium setting. Other climate control settings were adjusted for subject comfort. Midway through the car ride, the subject completed another SSR questionnaire. The subject returned to the EOHSI clinic immediately (post-exposure) and at $6 \mathrm{hr}$ and $24 \mathrm{hr}$ after the car ride for outcome measurements. Subjects ate a meal consisting of the same foods between the post-exposure and $6 \mathrm{hr}$ time points. For the 24-hr time-point, the subjects fasted again after midnight and returned to the EOHSI clinic at 7:00 AM to repeat a protocol identical to the pre-exposure protocol.

\section{Exposure measurements}

We made the following measurements with inlets at the subject's breathing zone inside the respirator face piece and near the center of the vehicle cabin: mass concentrations of PM with median cut-point of $2.5 \mu \mathrm{m}\left(\mathrm{PM}_{2.5}\right)$ at 1-min intervals using TSI SidePak model AM510 aerosol monitors (TSI, Inc, Shoreview, MN) with the calibration factor set at 0.32 (based on collocated gravimetric analysis of local ambient); number concentrations of particles with aerodynamic diameter from 0.01 to $1.0 \mu \mathrm{m}$ at 1 -min intervals using a condensation particle counter, TSI model 3007 (TSI, Inc.). Measured in the vehicle cabin only: back carbon using an AE-51 microaethalometer (Aethlabs, San Francisco, CA) at flow rate of $100 \mathrm{ml} / \mathrm{min}$ and 1-min time base; nitrogen dioxide $\left(\mathrm{NO}_{2}\right)$ collected on triethanolamine- 
coated Sep-Pak cartridges (Waters, Corp, Millford, MA), analyzed using HPLC-UV as previously reported [13]; carbon monoxide $(\mathrm{CO})$ and air temperature were measured continuously with a Langan T15v monitor (Langan, Inc, San Francisco, CA); and humidity with a $\mathrm{HOBO} 8$ Pro Series monitor (Onset, Bourne, MA).

\section{Exhaled breath condensate}

We collected 1-2 ml of EBC using an EcoScreen device (Jaeger, Wurzburg, Germany) with 20 minutes of tidal breathing. We triple rinsed all surfaces with nitrite-free water prior to contacting the $\mathrm{EBC}$, and froze samples at $-80 \mathrm{C}$ for later analysis. We measured concentrations of nitrite and nitrite + nitrate using selective catalytic reduction and chemiluminescence detection (NOA 280i, GE Analytics, Boulder Co.). The detection limits and precision for nitrite and nitrite + nitrate were $1 \mu \mathrm{M}$ and $8.2 \%$ (measured as \%RSD from 10 replicates) and $2.5 \mu \mathrm{M}$ and $12.0 \%$ (6 replicates), respectively.

For MDA analysis, a mixture of EBC, phosphoric acid, and thiobarbituric acid, was heated and injected into an HPLC-fluorescence system [50]. The detection limit, recovery and precision of this method were $1.8 \mathrm{nM}, 75.9 \%$, and $2.2 \%$ (8 replicates), respectively.

Concentrations of 8-isoprostane in EBC samples were analyzed using a modified immunoaffinity purification combined with a LC-MS/MS method [51]. After addition of $0.25 \mathrm{ng}$ of 8-iso- $\mathrm{PGF}_{2 \alpha}-\mathrm{D}_{4}$, the extract from 8-isoprostane affinity sorbent (Cayman, Ann Arbor, MI, USA) was analyzed on a quadrupole mass spectrometer (ThermoFisher Scientific, San Jose, CA, USA). The method recovery was $98.4 \%$ with analytic precision (8 replicates) of $11.2 \%$ and a detection limit of $2.5 \mathrm{pg} / \mathrm{mL}$.

\section{Heat rate variability}

A two-channel, three-lead, Holter monitor (Trillium 3000; Forest Medical, East Syracuse, NY) recorded ECG for 12 min with the subject lying supine at the preexposure, post-exposure, 6-hr and 24-hr time-points. For HRV analysis, the best quality (minimum artifact by visual inspection), continuous 5 -min period was selected from the last $7 \mathrm{~min}$ of the 12 -min recording. We processed the digital ECG signal, sampled at $256 \mathrm{~Hz}$, and calculated the HRV parameters using PC-based software (Trillium Gold; Forest Medical, East Syracuse, NY), after reviewing and correcting mislabeled beats or artifacts. We included all normal-to-normal $(\mathrm{NN})$ intervals in the 5 -min recording in computations of the standard deviation of normal to normal intervals (SDNN), square root of the mean of the squared differences between adjacent $\mathrm{NN}$ intervals (r-MSSD), high-frequency power (HF; 0.15 to $0.4 \mathrm{~Hz}$ ), low-frequency power (LF; 0.04 to $0.15 \mathrm{~Hz}$ ), and LF:HF ratio.

\section{Statistical analysis}

We used mixed linear models to evaluate the effect of exposure (unfiltered vs. filtered) on EBC and HRV outcomes, with post-exposure measures as the response, exposure as the predictor, and pre-exposure level of the corresponding measure as a covariate, with a random effect for subject. We used linear models to examine the effects of single pollutant levels during unfiltered rides on EBC markers at post-exposure time points. Statistical significance was set at $\alpha=0.05$.

\section{Competing interests}

The authors declare they have no actual or potential competing interest.

\section{Authors' contributions}

$\mathrm{RL}$ participated in the design of the study, performed heart rate variability (HRV) analysis, and drafted the manuscript. HK conceived of the study, participated in the design, and helped to draft the manuscript. KKM coordinated the study and acquired data. SK, CC, and AP participated in acquisition, organization, and analysis of data. MV analyzed and interpreted nitrite and nitrate data. JG characterized exposure to air pollutants. POS performed the statistical analysis and participated in interpretation of results. LZ and JG measured and analyzed environmental data. JZ helped to interpret results and draft manuscript. AG oversaw nitrite and nitrate analysis, and participated in interpretation and manuscript preparation. All authors read and approved the final manuscript.

\section{Acknowledgements}

This research was funded by the NIEHS under grant number ES005022 and T32ES007148.

\section{Author details}

'Department of Environmental and Occupational Medicine and the Environmental and Occupational Health Sciences Institute, Rutgers Robert Wood Johnson Medical School, 170 Frelinghuysen Rd, Piscataway, NJ 08854 USA. ${ }^{2}$ Department of Molecular Genetics, Cleveland Clinic, 9500 Euclid Avenue, Cleveland, $\mathrm{OH}$ 44195, USA. ${ }^{3}$ Biostatistics, Rutgers School of Public Health, 675 Hoes Lane, Piscataway, NJ 08854, USA. ${ }^{4}$ Nicholas School of the Environment and Duke Global Health Institute, Duke University, 450 Research Dr, Durham, NC 27708, USA. ${ }^{5}$ Pharmacy and Toxicology, Rutgers University, 160 Frelinghuysen Road, Piscataway, NJ 08854, USA.

Received: 17 March 2014 Accepted: 25 August 2014

Published online: 01 November 2014

\section{References}

1. Laumbach RJ, Kipen HM: Respiratory health effects of air pollution: update on biomass smoke and traffic pollution. J Allergy Clin Immunol 2012, 129:3-11. quiz 12-13.

2. Health Effects Institute: Traffic-Related Air Pollution: A Critical Review of the Literature on Emissions, Exposure, and Health Effects. In Book Traffic-Related Air Pollution: A Critical Review of the Literature on Emissions, Exposure, and Health Effects. City: Health Effects Institute; 2010.

3. Brook RD, Rajagopalan S, Pope CA III, Brook JR, Bhatnagar A, Diez-Roux AV, Holguin F, Hong Y, Luepker RV, Mittleman MA, Peters A, Siscovick D, Smith SC Jr, Whitesel L, Kaufman JD, and on behalf of the American Heart Association Council of Epidemiology and Prevention, Council on the Kidney in Cardiovascular Disease, and Council on Nutrition, Physical Activity and Metabolism: Particulate matter air pollution and cardiovascular disease. An update to the scientific statement from the American Heart Association. Circulation 2010, 121(21):2331-23378.

4. Zhu Y, Eiguren-Fernandez A, Hinds WC, Miguel AH: In-cabin commuter exposure to ultrafine particles on Los Angeles freeways. Environ Sci Technol 2007, 41:2138-2145.

5. Peters A, von Klot S, Heier M, Trentinaglia I, Hormann A, Wichmann HE, Lowel H, Cooperative Health Research in the Region of Augsburg Study G: Exposure to traffic and the onset of myocardial infarction. $N$ Engl J Med 2004, 351:1721-1730. 
6. Salvi S, Blomberg A, Rudell B, Kelly F, Sandstrom T, Holgate ST, Frew A: Acute inflammatory responses in the airways and peripheral blood after short-term exposure to diesel exhaust in healthy human volunteers. Am J Respir Crit Care Med 1999, 159:702-709.

7. Nordenhall C, Pourazar J, Blomberg A, Levin JO, Sandstrom T, Adelroth E: Airway inflammation following exposure to diesel exhaust: a study of time kinetics using induced sputum. Eur Respir J 2000, 15:1046-1051.

8. Mills NL, Tornqvist H, Robinson SD, Gonzalez M, Darnley K, MacNee W, Boon NA, Donaldson K, Blomberg A, Sandstrom T, Newby DE: Diesel exhaust inhalation causes vascular dysfunction and impaired endogenous fibrinolysis. Circulation 2005, 112:3930-3936.

9. Hussain S, Laumbach R, Coleman J, Youssef H, Kelly-McNeil K, Ohman-Strickland $\mathrm{P}$, Zhang J, Kipen H: Controlled exposure to diesel exhaust causes increased nitrite in exhaled breath condensate among subjects with asthma. J Occup Environ Med 2012, 54:1186-1191.

10. Kipen HM, Gandhi S, Rich DQ, Ohman-Strickland P, Laumbach R, Fan Z-H, Chen L, Laskin DL, Zhang J, Madura K: Acute decreases in proteasome pathway activity after inhalation of fresh diesel exhaust or secondary organic aerosol. Environ Health Perspect 2011, 119:658-663.

11. Lucking AJ, Lundback M, Mills NL, Faratian D, Barath SL, Pourazar J, Cassee FR, Donaldson K, Boon NA, Badimon JJ, Sandstrom T, Blomberg A, Newby DE: Diesel exhaust inhalation increases thrombus formation in man. Eur Heart J 2008, 29(24):3043-3051.

12. Langrish J, Mills N, Chan J, Leseman D, Aitken R, Fokkens P, Cassee F, Li J, Donaldson K, Newby D, Jiang L: Beneficial cardiovascular effects of reducing exposure to particulate air pollution with a simple facemask. Part Fibre Toxicol 2009, 6:8.

13. McCreanor J, Cullinan P, Nieuwenhuijsen MJ, Stewart-Evans J, Malliarou E, Jarup L, Harrington R, Svartengren M, Han IK, Ohman-Strickland P, Chung $\mathrm{KF}$, Zhang J: Respiratory effects of exposure to diesel traffic in persons with asthma. N Engl J Med 2007, 357(23):2348-2358.

14. Adar SD, Gold DR, Coull BA, Schwartz J, Stone PH, Suh H: Focused exposures to airborne traffic particles and heart rate variability in the elderly. Epidemiology 2007, 18:95-103.

15. Langrish JP, Li X, Wang S, Lee MM, Barnes GD, Miller MR, Cassee FR, Boon NA, Donaldson K, Li J, Li L, Mills NL, Newby DE, Jiang L: Reducing personal exposure to particulate air pollution improves cardiovascular health in patients with coronary heart disease. Environ Health Perspect 2012, 120(3):367-372

16. Laumbach RJ, Rich DQ, Gandhi S, Amorosa L, Schneider S, Zhang J, Ohman-Strickland P, Gong J, Lelyanov O, Kipen HM: Acute changes in heart rate variability in subjects with diabetes following a highway traffic exposure. J Occup Environ Med 2010, 52:324-331. 310.1097/ JOM.1090b1013e3181d1241fa.

17. Huang W, Zhu T, Pan X, Hu M, Lu SE, Lin Y, Wang T, Zhang Y, Tang X: Air pollution and autonomic and vascular dysfunction in patients with cardiovascular disease: interactions of systemic inflammation, overweight, and gender. Am J Epidemiol 2012, 176:117-126.

18. Weichenthal S, Kulka R, Dubeau A, Martin C, Wang D, Dales R: Traffic-related air pollution and acute changes in heart rate variability and respiratory function in urban cyclists. Environ Health Perspect 2011, 119:1373-1378.

19. Shields KN, Cavallari JM, Hunt MJ, Lazo M, Molina M, Molina L, Holguin F: Traffic-related air pollution exposures and changes in heart rate variability in Mexico City: a panel study. Environ Health 2013, 12:7.

20. Laumbach RJ, Kipen HM: Acute effects of motor vehicle traffic-related air pollution exposures on measures of oxidative stress in human airways. Ann N Y Acad Sci 2010, 1203:107-112.

21. Xia T, Korge P, Weiss JN, Li N, Venkatesen MI, Sioutas C, Nel A, Xia T, Korge P, Weiss JN, Li N, Venkatesen Ml, Sioutas C, Nel A: Quinones and aromatic chemical compounds in particulate matter induce mitochondrial dysfunction: implications for ultrafine particle toxicity. Environ Health Perspect 2004, 112(14):1347-1358.

22. Li N, Venkatesan MI, Miguel A, Kaplan R, Gujuluva C, Alam J, Nel A: Induction of heme oxygenase-1 expression in macrophages by diesel exhaust particle chemicals and quinones via the antioxidant-responsive element. J Immunol 2000, 165:3393-3401.

23. Pan CJ, Schmitz DA, Cho AK, Froines J, Fukuto JM, Pan C-JG, Schmitz DA Cho AK, Froines J, Fukuto JM: Inherent redox properties of diesel exhaust particles: catalysis of the generation of reactive oxygen species by biological reductants. Toxicol Sci 2004, 81:225-232.
24. Cheng WY, Currier J, Bromberg PA, Silbajoris R, Simmons SO, Samet JM: Linking oxidative events to inflammatory and adaptive gene expression induced by exposure to an organic particulate matter component. Environ Health Perspect 2012, 120:267-274

25. Manzo ND, LaGier AJ, Slade R, Ledbetter AD, Richards JH, Dye JA: Nitric oxide and superoxide mediate diesel particle effects in cytokine-treated mice and murine lung epithelial cells-implications for susceptibility to traffic-related air pollution. Part Fibre Toxicol 2012, 9:43.

26. Wan J, Diaz-Sanchez D: Antioxidant enzyme induction: a new protective approach against the adverse effects of diesel exhaust particles. Inhal Toxicol 2007, 19(Suppl 1):177-182.

27. Pourazar J, Mudway IS, Samet JM, Helleday R, Blomberg A, Wilson SJ, Frew AJ, Kelly FJ, Sandstrom T: Diesel exhaust activates redox-sensitive transcription factors and kinases in human airways. Am J Physiol Lung Cell Mol Physiol 2005, 289(5):L724-L730.

28. Manney S, Meddings CM, Harrison RM, Mansur AH, Karakatsani A, Analitis A, Katsouyanni K, Perifanou D, Kavouras IG, Kotronarou N, de Hartog JJ, Pekkanen J, Hameri K, ten Brink H, Hoek G, Ayres JG: Association between exhaled breath condensate nitrate plus nitrite levels with ambient coarse particle exposure in subjects with airways disease. Occup Environ Med 2012, 69(9):663-669.

29. Zhang J, Zhu T, Kipen H, Wang G, Huang W, Rich D, Zhu P, Wang Y, Lu SE, Ohman-Strickland P, Diehl S, Hu M, Tong J, Gong J, Thomas D, Committee H.E.I.H.R: Cardiorespiratory biomarker responses in healthy young adults to drastic air quality changes surrounding the 2008 Beijing Olympics. Res Rep Health Eff Inst 2013, 174:5-174.

30. Romieu I, Barraza-Villarreal A, Escamilla-Nuñez C, Almstrand A-C, Diaz-Sanchez D, Sly PD, Olin A-C: Exhaled breath malondialdehyde as a marker of effect of exposure to air pollution in children with asthma. J Allergy Clin Immunol 2008, 121:903-909. e906.

31. Gong J, Zhu T, Kipen H, Wang G, Hu M, Ohman-Strickland P, Lu SE, Zhang L, Wang Y, Zhu P, Rich DQ, Diehl SR, Huang W, Zhang JJ: Malondialdehyde in exhaled breath condensate and urine as a biomarker of air pollution induced oxidative stress. J Expo Sci Environ Epidemiol 2013, 23(3):322-327.

32. Huang W, Wang G, Lu SE, Kipen H, Wang Y, Hu M, Lin W, Rich D, Ohman-Strickland P, Diehl SR, Zhu P, Tong J, Gong J, Zhu T, Zhang J: Inflammatory and oxidative stress responses of healthy young adults to changes in air quality during the Beijing Olympics. Am J Respir Crit Care Med 2012, 186(11):1150-1159.

33. Pieters N, Plusquin M, Cox B, Kicinski M, Vangronsveld J, Nawrot TS: An epidemiological appraisal of the association between heart rate variability and particulate air pollution: a meta-analysis. Heart 2012, 98:1127-1135.

34. Park SK, O'Neill MS, Vokonas PS, Sparrow D, Schwartz J: Effects of air pollution on heart rate variability: the VA normative aging study. Environ Health Perspect 2005, 113:304-309.

35. Park SK, O'Neill MS, Wright RO, Hu H, Vokonas PS, Sparrow D, Suh H, Schwartz J: HFE genotype, particulate air pollution, and heart rate variability: a gene-environment interaction. Circulation 2006, 114:2798-2805

36. Balint B, Donnelly LE, Hanazawa T, Kharitonov SA, Barnes PJ: Increased nitric oxide metabolites in exhaled breath condensate after exposure to tobacco smoke. Thorax 2001, 56:456-461.

37. Gessner C, Hammerschmidt S, Kuhn H, Hoheisel G, Gillissen A, Sack U, Wirtz $\mathrm{H}$ : Breath condensate nitrite correlates with hyperinflation in chronic obstructive pulmonary disease. Respir Med 2007, 101:2271-2278.

38. Robroeks CM, van de Kant KD, Jobsis $Q$, Hendriks HJ, van Gent R, Wouters EF, Damoiseaux JG, Bast A, Wodzig WK, Dompeling E: Exhaled nitric oxide and biomarkers in exhaled breath condensate indicate the presence, severity and control of childhood asthma. Clin Exp Allergy 2007, 37(9):1303-1311.

39. Corradi M, Pesci A, Casana R, Alinovi R, Goldoni M, Vettori MV, Cuomo A: Nitrate in exhaled breath condensate of patients with different airway diseases. Nitric Oxide 2003, 8(1):26-30.

40. Zhu Y, Hinds WC, Kim S, Sioutas C: Concentration and size distribution of ultrafine particles near a major highway. J Air Waste Manag Assoc 2002, 52:1032-1042.

41. Adar SD, Adamkiewicz G, Gold DR, Schwartz J, Coull BA, Suh H: Ambient and microenvironmental particles and exhaled nitric oxide before and after a group bus trip. Environ Health Perspect 2007, 115:507-512. 
42. Riediker M, Devlin R, Griggs T, Herbst M, Bromberg P, Williams R, Cascio W: Cardiovascular effects in patrol officers are associated with fine particulate matter from brake wear and engine emissions. Part Fibre Toxicol 2004, 1:2.

43. Weichenthal S, Kulka R, Belisle P, Joseph L, Dubeau A, Martin C, Wang D, Dales R: Personal exposure to specific volatile organic compounds and acute changes in lung function and heart rate variability among urban cyclists. Environ Res 2012, 118:118-123.

44. Mills NL, Finlayson AE, Gonzalez MC, Tornqvist H, Barath S, Vink E, Goudie C, Langrish JP, Soderberg S, Boon NA, Fox KAA, Donaldson K, Sandstrom T, Blomberg A, Newby DE: Diesel exhaust inhalation does not affect heart rhythm or heart rate variability. Heart 2011, 97(7):544-550.

45. Peretz A, Sullivan JH, Leotta DF, Trenga CA, Sands FN, Jason A, Carlsten C, Wilkinson CW, Gill EA, Kaufman JD: Diesel exhaust inhalation elicits acute vasoconstriction in vivo. Environ Health Perspect 2008, 116:937-942.

46. Harber P, Tamimie RJ, Bhattacharya A, Barber M: Physiologic effects of respirator dead space and resistance loading. J Occup Med 1982, 24:681-689.

47. Louhevaara VA: Physiological effects associated with the use of respiratory protective devices. A review. Scan J Work Environ Health 1984, 10:275-281.

48. Marteus H, Tornberg DC, Weitzberg E, Schedin U, Alving K: Origin of nitrite and nitrate in nasal and exhaled breath condensate and relation to nitric oxide formation. Thorax 2005, 60:219-225.

49. Zetterquist $W$, Marteus $H$, Kalm-Stephens $P$, Nas E, Nordvall L, Johannesson M, Alving K, Zetterquist W, Marteus H, Kalm-Stephens P, Nas E, Nordvall L, Johannesson M, Alving $K$ : Oral bacteria-the missing link to ambiguous findings of exhaled nitrogen oxides in cystic fibrosis. Respir Med 2009, 103(2):187-193.

50. Larstad M, Ljungkvist G, Olin A-C, Toren K: Determination of malondialdehyde in breath condensate by high-performance liquid chromatography with fluorescence detection. J Chromatogr B Analyt Technol Biomed Life Sci 2002, 766:107-114.

51. Syslova K, Kacer P, Kuzma M, Klusackova P, Fenclova Z, Lebedova J, Pelclova D: Determination of 8-iso-prostaglandin $\mathrm{F}$ (2alpha) in exhaled breath condensate using combination of immunoseparation and LC-ESI-MS/MS. J Chromatogr B Analyt Technol Biomed Life Sci 2008, 867:8-14.

doi:10.1186/s12989-014-0045-5

Cite this article as: Laumbach et al: A controlled trial of acute effects of human exposure to traffic particles on pulmonary oxidative stress and heart rate variability. Particle and Fibre Toxicology 2014 11:45.

\section{Submit your next manuscript to BioMed Central and take full advantage of:}

- Convenient online submission

- Thorough peer review

- No space constraints or color figure charges

- Immediate publication on acceptance

- Inclusion in PubMed, CAS, Scopus and Google Scholar

- Research which is freely available for redistribution

Submit your manuscript at www.biomedcentral.com/submit
(O) Biomed Central 